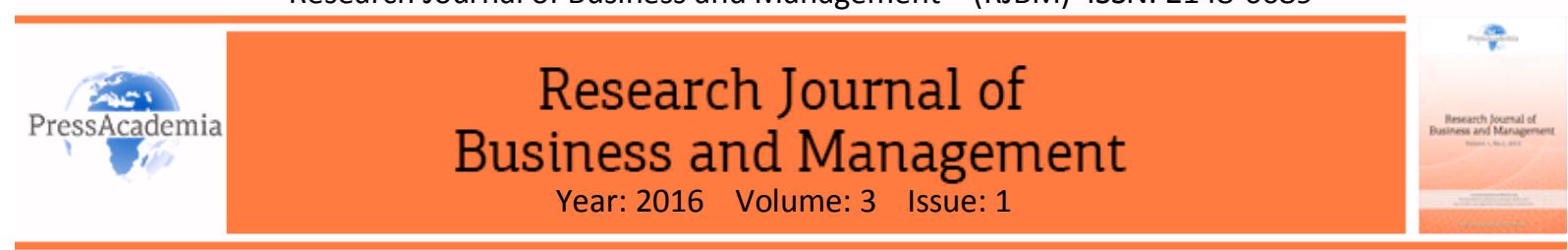

\title{
THE ASSOCIATION BETWEEN PERCEIVED JOB INSECURITY AND CAREER COMMITMENT IN HOSPITALITY SECTOR: THE ROLE OF SUPPORT AT WORK
}

\author{
DOI: 10.17261/Pressacademia.2016116541
}

Banu S. Unsal Akbiyik ${ }^{1}$

${ }^{1}$ Kocaeli University. banu.unsal@kocaeli.edu.tr

\begin{abstract}
he purpose of this study is to investigate the relationship between perceived job insecurity, career commitment. The study also attempts to examine the mediating effect of support at work on this relationship. A survey from 186 hospitality employees was analyzed using mediated regression analysis. The results demonstrate that perceived job insecurity is negatively related to career commitment. High supervisor and peer support contributes to career commitment and mediates the association between the association perceived job security and career commitment. It is recommended that managers focus on support at work in the working environment to decrease the negative effect of perceived job insecurity.
\end{abstract}

Keywords : Perceived job insecurity, career commitment, perceived supervisor support, perceived peer support, hospitality industry. JEL Classification : D23, M12, L83

\section{INTRODUCTION}

Numerous organizations worldwide have undergone downsizing, mergers and acquisitions and restructuring (Chang \& Chan, 2008). Careers within a single organization are becoming difficult, career changes and job mobility have become common phenomena (Rousseau et al., 1996). These developments have lessened organizational tenure and created feelings of insecurity in employees (Cappelli et al., 1997). Literature show that that heightened job insecurity create negative job related attitudes and behaviors and increase turnover (e.g., Hartley, 1998; Mathieu \&Zajac, 1990; Meyer \& Allen, 1997, Sverke et al., 2002; ; Probst, 2003). The primary purpose of this article is to examine the association between job insecurity and career commitment among employees in hospitality sector.

Career commitment has received the least attention in all forms of work commitment (Niu, 2010). London (1983) posited that a number of personal and situational factors may influence and/or reflect career commitment. Situational variables usually are not investigated in previous research (Goulet and Singh, 2002). Job insecurity may be having an impact on career commitment because of organizational and economical changes in the late 1990's. When employees experience increased job insecurity, they might look elsewhere for a possible future job opportunity and develop career related skills. However, this assumption is a problematic area. This does not mean that increased job insecurity leads to increased career commitment for all kind jobs.

A number of studies have examined the organizational and personal consequences of job insecurity and found that it negatively impacted job performance resulted in attitudinal reactions such as intention to quit, reduced organizational commitment, and reduced satisfaction (De Cuyper et al., 2010; Greenhalgh, 1982). In this study, it is assumed that if individuals have job insecurity, they have less commitment to their profession or career to develop skills and show more intention of withdrawing from their career and job in hospitality industry. According to Greenhalgh and Rosenblatt (2010), there are limited researches to explain the relationship between job insecurity and its consequences through mediating variables. It will be further investigated whether support at work mediate this relation. 
The present study contributes to the literature in two specific ways. First, literature review shows that there are not many studies focusing on the association between job insecurity and career commitment. Research regarding career commitment has been conducted mostly in professional careers such as lawyers, nurses (Mathieu \&Zajac, 1990; Wallace, 1995). There is little published research on career commitment and its impacts on employee in hospitality industry (e.g. Kim et al., 2012 Niu, 2010; Lam, 2003). This study therefore allows us to extend the research on job insecurity by examining the relationship between perceived job security and career commitment in hospitality sector in Istanbul. Second, the majority of perceived job insecurity research has been carried out in developed countries and there is still a paucity of knowledge on this issue in the context of developing countries (Otluoglu and Ünsal, 2015). Many employees in Turkey experience job insecurity since the unemployment rate, which has a significant impact on perceived job insecurity (Erlinghagen, 2008), was 9.1\% in the first quarter of 2014 in Turkey, higher than the average of OECD (OECD, 2014).Thus, sampling in a Turkish context, where the job insecurity comes into prominence, contributes to national and international literature.

\section{LITERATURE REVIEW}

\subsection{Career Commitment and Perceived Job Insecurity}

Career commitment may be defined as "one's attitude towards one's profession or vocation" (Blau, 1985, p. 278) or as "one's motivation to work in a chosen vocation" (Carson \&Bedeian, 1994, p. 240). Career commitment is also referred to occupational commitment (Meyer, Allen, \& Smith, 1993), professional commitment (Wallace, 1995), or career motivation (London \& Noe, 1997). In general, career commitment involves the development of personal career goals and an identification with and involvement in those goals (Collarelli\& Bishop, 1990). More specifically, in this study, Blau's (1985) conceptualization of the variable was used, focusing on employee's attitude towards his or her vocation.

Commitment to one's career affects an individual's behavior. Individuals who are highly committed to their career have been shown to spend more time in developing skills, and show less intention of withdrawing from their career and job (Aryee and Tan, 1992; Blau, 1989). Career commitment is an important issue for a person's career development because it affects future decisions, actions and performance (Lent et al., 1996). A commitment to a career, an occupation is based on the premise that one chooses a career with certain expectations and one's decision to remain in a particular career are influenced by whether or not her/his expectations are satisfied by the realities s/he experiences (Ugboro\&Obeng, 2015). The hospitality industry is oftencharacterized by notoriously poor wages, low job security, long working hours, limited opportunities for personal development (Kuşluvan\&Kuşluvan, 2003). Employees' levels of expectations are usually misfit with their perceived realities in hospitality sector due to these adverse jobs attributes. This creates high turnover rate (Dawson et al., 2011). Employees in that industry have not intended to stay for a long time. Literature review indicates that tourism-oriented employment is mainly perceived negatively by those working in the industry (Kusluvan and Kusluvan, 2000; Richardson, 2009).

Job insecurity is generally defined as an overall concern about the continued existence of the job in the future, feelings related to deterioration of working conditions and salary cuts or the impossibility of career development (Greenhalgh\& Rosenblatt, 1984; Sverke\&Hellgren, 2002). Even though several authors treat job insecurity as an objective situation (Büssing, 1999; Ferrie, et al., 1998), most authors consider job insecurity as a subjective experience based on an individual's perception of the current situation (De Witte, 1999; Sverke\&Hellgren, 2002).Employees who experience job insecurity may decrease their commitment to the organization (De Witte and Naswall, 2003; Hartley et al., 1991; Sverke et al., 2002, Vujicic, et al., 2015).Based on the argument on cognitive dissonance theory, employees increase the value of their commitment to the occupation when commitment to the organization is reduced by threatened job insecurity (McAulay et al., 2006). These arguments are unproven and based on inadequate research findings for all kind of jobs. According to social identity theory (Tajfel\&Turner,1985), employees identify themselves with their occupation and become more committed to their occupation. Such identification allows the employee to locate themselves to occupational community (McAulay et al., 2006). However, with respect to the hospitality sector only, since the employee turnover remains one of the most troubling issues (Ghiselli et al., 2001), employees in hospitality 
industry may not develop their commitment to their occupation. More precisely, these employees might not like to pursue their career because of adverse job attributes. On that basis, being a member of an occupational community might not have an affirmative impact on occupational commitment for the employees in hospitality sector.

Situational characteristics are important predictors of career commitment (Ballout, 2009). Goulet and Singh (2002) indicated that fear of job loss is negatively related with career commitment in profit and nonprofit organizations and Ugboro and Obeng (2015) found negative relation between perceived job insecurity and career commitment among university professors. This study focuses on hospitality sector in Istanbul. If employees don't perceive any job security in their organization, commitment to their vocation might decrease

We therefore suggest that concerns about employment discontinuity in the current organization might make employees uncommitted to their career. We propose the following hypothesis.

H1: Perceived job insecurity is negatively related to career commitment.

\subsection{The Mediation of Support at Work}

According to Greenhalgh and Rosenblatt (2010), there is research gap to explain the relationship between job insecurity and its consequences through mediating variables. The meta-analysis conducted by Sverke and his colleagues (2002) showed that job insecurity was negatively related to trust. Perceived support from organization, supervisor and peer would create trust that the organization will fulfill its exchange obligations of noticing and rewarding employee effort made on its behalf. For job insecurity, we expect perceived organizational support will act as a mediator. It has been suggested by Ashford et al. (1989) that these two notions are interrelated. For an employee perceives job insecurity, perceived organizational support may be crucial factor for their career commitment.

Organizational support theory assumes that when the organization fairly evaluates employees' contributions and efforts, employees form general beliefs concerning how much organization values their contribution and their well-being (Eisenberger et al. 1997). Organizational rewards, promotion, job enrichment, participation in decision making all contribute to perceived organizational support (Rhoades \&Eisenberger, 2002). These job conditions and organizational rewards mean positive evaluation of employees' contributions and thus contribute to perceived organizational support. They are all related with organizational career growth. The degree that an organization provides for career growth should enhance employee's career commitment (Weng\& McElroy, 2012). Previous research indicates that perceived organizational support has been positively related to commitment (Eisenberger et al., 1990; Tanksy\& Cohen, 2001; Whitener, 2001). It can be assumed that perceived organizational support is related with career commitment. When employees felt more insecure in their job, their perceived organizational support will mediate the association between job insecurity and career commitment. The negative effect of job insecurity on career commitment becomes insignificant. It is therefore proposed the following hypothesis:

H2a: Perceived organizational support will mediate the relationship between job insecurity and career commitment

Supervisor support affects subordinates attitudes to their careers (Kidd \&Smewing, 2001). It has shown to be positively related to career commitment (Aryee et al., 1994; Darden et al., 1989). Supervisor support provides opportunities to subordinates to develop and strengthen new skills, taking the time to learn about subordinates' career goals and aspirations, and supporting subordinates' attempts to acquire additional training or education to further their careers (Otluoglu, 2012). Support from supervisor facilitates subordinate's career advancement and result in a higher level of career commitment. This alleviates the negative effect of perceived job insecurity. It would propose the higher level of perceived supervisor support an employee has the higher and more developed career commitment that the employee has. When employees feel insecure in their job, their perceived supervisor support will mediate the association between job insecurity and career commitment. It is therefore proposed the following hypothesis: 
$\mathrm{H} 2 \mathrm{~b}$ : Perceived supervisor support will mediate the relationship between job insecurity and career commitment

Support from co-workers can relieve one's stress at work because an individual employee generally believes that there is shared trust, emotional support, and cooperation between himself or herself and his or her coworkers (Lau \&Liden, 2008). Employees who perceive high support in coworkers have shown higher levels of job satisfaction and organizational commitment than employees who perceive less support from their coworkers (Tharenou et al. 1994). As such, higher perceived peer support is positively related to career commitment and organizational commitment as a whole (Wallace, 1995). When employees feel insecure in their job, their perceived peer support will mediate the association between job insecurity and career commitment.It is therefore proposed the following hypothesis:

H2c: Perceived peer support will mediate the relationship between job insecurity and career commitment.

\section{DATA AND METHODOLOGY}

\subsection{Participant and Procedures}

The data was collected from hospitality employees who were working in five star hotels located in Istanbul. The sampling frame on this study was based on the 57 five star hotels in Istanbul listed by the Governorship of the City and the Directorate of Tourism (2013). Data collection took from March 2015 to June 2015. It was requested to get permission from human resource manager to distribute the survey in their hotels which resulted in distribution in 20 hotels. In total, 260 questionnaires and self-seal envelopes were left with human resource manager to be distributed to all staff.Each questionnaire included a letter of information about the research project, ensured the participants confidentiality and included instructions to seal the questionnaire in the envelope after responding, or to return the blank questionnaire in the same envelope if they chose not to respond. Questionnaires were collected two or three weeks after their distribution. A total of 213 sealed envelopes were returned; after eliminating those that were blank, 180 questionnaires were found usable giving a $69 \%$ response rate.

\subsection{Measures}

Perceived job insecurity was measured using seven-item scale of Zeytinoglu et al. (2007). The items were scored on a 5-point scale, ranging from 1 (strongly disagree) to 5 (strongly agree). A sample item of the scale was "I'm presently safe from dismissal at this organization". The Cronbach alpha for this scale in the present study was .80 .

Career commitment was measured by using eight-item scale of Blau's (1985) career commitment scale. The items were scored on a 5-point scale, ranging from 1 (strongly disagree) to 5 (strongly agree). A sample item is "I like this vocation to well to give it up". The Cronbach alpha for this scale in the present study was .86.

Support at work has three different types of support included as mediating variables. Organizational and supervisor support scales were each measured using six-items and peer support was measured using fouritems from Denton et al. (2007). A sample item for each scale was: 'My workplace supports me in time of personal crisis, illness or needing time off to help care for other family members'; 'My supervisor appreciates my work'; 'The people I work with take a personal interest in me'. The scales showed a good reliability with high Cronbach's alphas ( $\alpha=0.73,0.89,0.92$, respectively).

Being older, with longer tenure and education are all associated with career commitment. In this study, we control for the effects of these factors and focus on perception of job security and their association with career commitment. They were coded as: gender (' $1=$ male', ' $0=$ female'), tenure (years), education (' $1=$ university degree including 2-year college degree', ' $0=$ high school or lower'). Importance of income for the family can be as a proxy for perceived job insecurity (Zeytinoglu, 2012). Thus, it is included as a variable controlling for its possible association with career commitment (coded as ' $1=$ not important' to ' $5=$ very important'). 
The scales were translated into Turkish by the authors and the translated scales were back translated into English by a bilingual academic (Brislin, 1986). The items that showed discrepancies were re-written to be clear and back-translated again.

\subsection{Analysis}

Descriptive statistics, Cronbach's alphas were conducted first. Prior to analyses, checks of the theoretical assumptions underlying regression analysis were undertaken, including normality, linearity, and homoscedasticity. In order to investigate these assumptions, a histogram, a normal probability plot and a linear regression plot were interpreted and no extreme deviations were identified. To show the variance explained by the factors in the study, $R^{2}$ and adjusted $R^{2}$ were provided. We checked the Variance Inflation Factors (VIFs) of all variables. The results showed that VIFs ranged between 1.30 and 2.15 which is well below the suggested cutoff value of 10 (Pedhazur, 1997). Therefore, we rule out any concerns about multicollinearity of independent variables. Further, to test for common method variance, we run Harman's single-factor test to point out if the majority of the variance can be explained by single factor (Podsakoff et al., 2003). CMV is not likely a concern.Next, it was examined the association between variables using bivariate correlation tests. Following that, it was proceded to hierarchical regression analysis. Mediation tests were conducted using the three-stage regression analysis method of Baron and Kenny (1986). Conditional for mediation was (1) perceived job security was related with perceived organizational support-supervisor support-peer support; (2) perceived job security was related to career commitment $(\mathrm{H} 1)$; (3) that perceived organizational supportsupervisor support-peer support was related to career commitment. For this, first control variables were entered in the analysis, and followed by the independent variables in the second step and then mediator in the third step. To show the variance explained by these factors, $R^{2}$ as well as Adjusted $R^{2}$ were conducted.

\section{EMPIRICAL FINDINGS}

\subsection{Descriptive Statistics}

As presented in Table 1, males comprised $67.7 \%$ of the sample. The average organizational experience is 9.99 years $(S D=8.61)$, ranging from 1-45. $61 \%$ of the participants had a high school or lower degree. The participants' income from the job was high important for their family $(M=4.35, S D=1.13)$. For perceived job insecurity, respondents perceived insecurity in their jobs $(M=3.95, S D=0.74)$. Most of the participants perceived organizational-supervisor-peer support. ( $M=3.95, S D=1.05 ; M=4.05, S D=0.75 ; M=4.15, S D=0.60$ respectively). For career commitment, they were somewhat more committed to their career $(M=3.63, S D=0.92)$.

\subsection{Correlations}

Descriptive statistics and intercorrelations of the study variables are presented in Table 1. Perceived job insecurity was significantly and negatively associated with career commitment $(-0.235, p \leq .01)$. Organizationalsupervisor-peer support were all significantly and negatively associated with perceived job insecurity $(-0.395, p$ $\leq .01 ;-0.387, \mathrm{p} \leq .01 ;-0.290, \mathrm{p} \leq .01$, respectively). They were all significantly and positively associated with career commitment (0.189, $\mathrm{p} \leq .05 ; 0.370, \mathrm{p} \leq .01 ; 0.300, \mathrm{p} \leq .01$, respectively). Career commitment is also significantly and positively associated with the importance of income to family $(0.234, p \leq .01)$. 
Table 1: Descriptive Statistics and Intercorrelations of Study Variables

\begin{tabular}{|c|c|c|c|c|c|c|c|c|c|c|c|}
\hline Variable & $M$ & SD & 1 & 2 & 3 & 4 & 5 & 6 & 7 & 8 & 9 \\
\hline 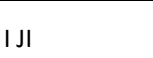 & 3.95 & 0.74 & 1 & $-.235 * *$ & $-.395 * *$ & $-.387 * *$ & $-.290 * *$ & -.005 & -.054 & .124 & .036 \\
\hline 2.CC & 3.63 & 0.92 & $-.235^{* *}$ & 1 & $.189 *$ & $.370 * *$ & $.300 * *$ & .132 & $.234 * *$ & .083 & .193 \\
\hline 3.POS & 3.95 & 1.05 & $-.395^{*}$ & $.189 *$ & 1 & $.364 * *$ & $.184 * *$ & -.008 & -.016 & $-.19 *$ & -.081 \\
\hline 4.PSS & 4.05 & 0.75 & $-.387 * *$ & $.370 * *$ & $.364 * *$ & 1 & $.436 * *$ & .108 & .175 & -.056 & $.214^{*}$ \\
\hline 5.PPS & 4.15 & 0.60 & $-.290 *$ & $.300 * *$ & $.184^{*}$ & $.436 * *$ & 1 & -.036 & .055 & .005 & .009 \\
\hline 6.Gender & - & - & -.005 & .132 & -.008 & .106 & -.036 & 1 & -.096 & $.207^{*}$ & .155 \\
\hline $\begin{array}{l}\text { 7.Imp.of inc } \\
\text { to fam. }\end{array}$ & 4.35 & 1.13 & -106 & $.234 * *$ & -.016 & .175 & .055 & -.096 & 1 & $.282^{*}$ & .102 \\
\hline 8.Ed. level & - & - & .124 & .003 & $-.197 * *$ & -.056 & .005 & $.207^{*}$ & $282^{* *}$ & .1 & $208^{*}$ \\
\hline $\begin{array}{l}\text { 9.0rg. } \\
\text { tenure }\end{array}$ & 9.99 & 8.61 & -.036 & $.193^{*}$ & -.081 & $.214^{*}$ & .009 & .155 & .102 & $.208^{*}$ & 1 \\
\hline
\end{tabular}

${ }^{*} \mathrm{p} \leq .05,{ }^{* *} \mathrm{p} \leq .01,{ }^{* * *} \mathrm{p} \leq .001$; Perceived job insecurity=Jl; CC=Career Commitment; POS=Perceived Organizational Support; PSS=Perceived Supervisor Support; PPS=Perceived Peer Support

\subsection{Regression Results}

To investigate condition (1) on the relationship between job insecurity and perceived organizational supportsupervisor support-peer support, it was regressed the control variables (step 1) and perceived job insecurity (step 2) on perceived organizational support-supervisor support-peer support. Table 2 presents the second step of the hierarchical regression results for variables associated with the three forms of support at work. Perceived job insecurity showed a significant and negative association with organizational support-supervisor support-peer support $(6=-0.38, * * * p \leq .001,6=-0.37, * * * p \leq .001$ and $6=-029, * * * p \leq .001$ respectively). With control variables included the model explained $15 \%$ of the variance in organizational support, $17 \%$ of the variance in supervisor support and $5 \%$ of the variance in peer support. Condition (1) was supported.

Table 2: Association between Perceived Job Insecurity and Support at Work

\begin{tabular}{|c|c|c|c|c|c|c|}
\hline & \multicolumn{2}{|c|}{ POS } & \multicolumn{2}{|c|}{ PSS } & \multicolumn{2}{|c|}{$\underline{\text { PPS }}$} \\
\hline & B & S.E. & $\mathrm{B}$ & S.E. & $\mathrm{B}$ & S.E. \\
\hline Zonstant & 5.20 & 0.53 & 4.54 & .0 .438 & 4.88 & 0.68 \\
\hline Jender & 0.09 & 0.20 & 0.160 & 0.168 & -0.09 & 2.62 \\
\hline $\mathrm{mp}$. of income to family & -0.01 & 0.07 & 0.12 & 0.06 & 0.11 & 0.10 \\
\hline ¿ducation level & -0.32 & 0.19 & -0.12 & 0.16 & 0.12 & 0.25 \\
\hline Jrg.tenure & -0.12 & 0.14 & 0.20 & 0.01 & 0.01 & 0.02 \\
\hline Jerceived Job Insecurity & $-0.53 * * *$ & 0.12 & $-0.43 * * *$ & 0.09 & $-0.51 * * *$ & 0.15 \\
\hline $2^{2}$ & 0.18 & & 0.20 & & 0.09 & \\
\hline Adjusted $\mathrm{R}^{2}$ & $0.15^{* *}$ & & $0.17 * * *$ & & $0.05^{* * *}$ & \\
\hline v & 186 & & 186 & & 186 & \\
\hline
\end{tabular}

${ }^{*} \mathrm{p} \leq .05,{ }^{* *} \mathrm{p} \leq .01,{ }^{* * *} \mathrm{p} \leq .001, \mathrm{POS}=$ Perceived Organizational Support; PSS=Perceived Supervisor Support; PPS=Perceived Peer Support 
The results of hierarchical regression analyses about the association between perceive job insecurity and career commitment are presented in Table 3. It was regressed the control variables (step 1) and perceived job insecurity (step 2) on career commitment. Perceived job insecurity was significantly and negatively associated with career commitment, $(B=-0.21, p \leq .01)$. Perceived job insecurity contributed to the variance explained (Adj. $\mathrm{R}^{2}=0.11, \Delta \mathrm{R}^{2}=0.15,{ }^{*} \mathrm{p}$ «.01)for career commitment. According to the result, perceived job insecurity demonstrate significantly and negatively relationship with career commitment, supporting hypothesis1

Evidence for mediation was found when perceived job insecurity had a smaller or non-significant relationship with the outcomes when introducing perceived organizational support-supervisor support-peer support (regression equation described in condition 3 as compared to the regression equation in which perceived organizational support-supervisor support-peer support was not introduced (regression equation described in condition 2. To investigate conditions 2 and 3, the control variables were entered in the first step, perceived job security in the second step, and perceived organizational support-supervisor support-peer support in the third step separately. The relationship between perceived job security and career commitment was no longer significant when introducing support at variables in the regression analyses. It was inspected the third step of the regression analyses shown in Table 3. When perceived organizational support, perceived supervisor support and perceived peer support were included in the analysis, controlling for other factors, perceived supervisor support and perceived peer support significantly and positively associated with career commitment $(b=-0.27, * * p \leq .01 ; b=0.24, * * p \leq .01$ and respectively). According to the results, perceived supervisor-peer support mediate the association between perceived job insecurity and career commitment, supporting hypothesis $2 b$ and hypothesis $2 c$. The significant effect of perceived job insecurity disappeared suggesting mediation effect. However, perceived organizational support did not demonstrate mediation effect, rejecting hypothesis 2a. The control variables added significantly in predicting career commitment in the model. The variables in the model that supervisor support is a mediator explained $17 \%$ of the variance $\left(\operatorname{Adj} . R^{2}=0.17, \Delta\right.$ $R^{2}=0.21 \mathrm{p}$.01). The variables in the model that peer support is a mediator explained $16 \%$ of the variance (Adj. $R^{2}=0.16, \Delta R^{2}=0.20$ pr.01).

Table 3: Perceived Job insecurity and Control Factors with Career Commitment with Support at Work Included as a Mediator

\begin{tabular}{|c|c|c|c|c|}
\hline & CC ( $\left(2^{\text {nd }}\right.$ Step $)$ & CC with POS & CC with PSS & CC with PPS $\left(3^{\text {rd }}\right.$ Step) \\
\hline & B & B & B & B \\
\hline Constant & 2.969 & 2.2 .54 & 1.869 & 2.124 \\
\hline Gender & 0.28 & 0.28 & 0.22 & 0.30 \\
\hline $\begin{array}{l}\text { Imp. of income } \\
\text { to family }\end{array}$ & 0.20 & 0.20 & 0.17 & 0.19 \\
\hline Education level & -0.05 & -0.10 & 0.01 & -0.06 \\
\hline Org.tenure & 0.01 & 0.02 & 0.10 & 0.02 \\
\hline $\begin{array}{l}\text { Perceived Job } \\
\text { Insecurity }\end{array}$ & $-.0 .24 * *$ & -0.18 & -0.13 & -0.16 \\
\hline POS & - & 0.13 & - & - \\
\hline PSS & - & - & $0.30 * *$ & - \\
\hline PPS & - & - & - & $0.18^{* *}$ \\
\hline $\mathrm{R}^{2}$ & 0.15 & 0.18 & 0.21 & 0.20 \\
\hline Adjusted $\mathrm{R}^{2}$ & 0.11 & 0.14 & $0.17^{* *}$ & $0.16 * *$ \\
\hline $\mathrm{N}$ & 186 & 186 & 186 & 186 \\
\hline
\end{tabular}

${ }^{*} \mathrm{p} \leq .05,{ }^{* *} \mathrm{p} \leq .01,{ }^{* *} \mathrm{p} \leq .001 ; \mathrm{CC}=$ Career Commitment; POS=Perceived Organizational Support; PSS=Perceived Supervisor Support; PPS=Perceived Peer Support 


\section{ANALYSIS OF FINDINGS}

The primary purpose of this study is to investigate the relationship between career commitment and perceived job insecurity among employees in hospitality industry in Istanbul. Result of this study show that perceived job insecurity is significantly and negatively associated with career commitment in hospitality sector in Istanbul. This study finding is contradiction to earlier research findings that are somewhat problematic (McAuley et al., 2006). Recent literature has focused on the positive effect on the association between job insecurity and career commitment. However, The hospitality industry is often characterized by notoriously poor wages, low job security, long working hours, limited opportunities for personal development (Kuşluvan\&Kuşluvan, 2003). A turnover culture permeates in hospitality sector. The turnover rate for five-star hotels is $85 \%$ (Bas-Collins, 2007). Job insecurity is a norm in that industry. Therefore these employees might refrain from pursuing their careers in this sector and search job in another occupation.

Employees with increased job insecurity are less committed to their careers. Employees may be viewing career commitment along traditional career paths. Employees become more focused on their personal selfdevelopment, which may mean changing job or career, rather than be committed to traditional career paths (Goulet \& Singh, 2000). The assumption of this study was that perceived job insecurity is significantly and negatively related with career commitment. The result of the study, as well, confirms this assumption.

The secondary purpose of the study is to investigate the mediation effect of organizational-supervisor-peer support on the relationship between perceived job insecurity and career commitment among employees in hospitality industry in Istanbul. Result of this study indicates that perceived supervisor and peer support mediate the effect of perceived job insecurity on career commitment. Supervisor support gives subordinates the opportunity to develop and strengthen new skills (Otluoglu, 2012). If supervisor is supportive in providing career opportunities and feedback; employees might sense more clarity in career opportunities and advancement in the company (Chang, 1999). The effect of perceived supervisor support can alleviate the negative effects of job insecurity. Peer relationships offer a variety of career-related and psychosocial functions. Peer relationship appear more likely to occur and more necessary to career development (Cohen, 1994). It can provide social support (Allen et al., 1999). Peer support can mitigate the negative effects of job insecurity. Thus, support at work is crucial for career commitment.

However, perceived organizational support does not mediate the association between perceived job insecurity and career commitment. Employees who experience job insecurity are less likely to trust their organization. Job insecurity can threaten employees' attitudinal and emotional attachment to the organization because it breaks up the trustworthy relationship of the employees with their organization (Sora et al., 2009). Organizational support conveys the idea that an organization strongly values the employees' contributions, leading to feel in secure environment (Caesens, et al. 2015). Employees highly feel job insecurity; it impedes employees' perception of organizational support.

\section{CONCLUDING REMARKS}

There are a few limitations that need to be addressed regarding the findings of the present study. First, the sample comes from only five star hotels in Istanbul. The sample is unrepresentative of the general population. Results cannot be generalized to all Turkish hospitality sector employees or similarly situated hospitality sector employees in other countries. Future research can be conducted for other professional occupation. Second, self-reported cross-sectional data is another limitation. It only shows associations between variables. More longitudinal studies across organizations are needed to show casual inferences. Third, the present study focused on the mediation effect of perceived organizational-supervisor-peer support. Future research could benefit from individual variables or other situational variables as mediators or moderators.

The main practical implication of this study is that these findings confirm the negative link between perceived job insecurity and career commitment among employees in hospitality sector in Istanbul. Besides this, perceived supervisor and peer support might alleviate negative effect of perceived job insecurity. Supervisor and peer support assist employees in coping with job security in a manner that is less detrimental to them. It is recommended manager to foster supporting supervisor-subordinate, peer-peer relationship. Managers can 
reinforce to develop systems that their employees can perceive to be cared and supported by their supervisors and peers. They can create better working environments conducive to career commitment through effective performance evaluation systems, mentoring function,team work.If employees in hospitality sector feel fear of job loss, they might remain in their career and develop their career related skills with the help of supervisors and peers. They become more qualified and valuable.

\section{REFERENCES}

Allen, T. D., McManus, S. E. and Russell, J. E. A. (1999), "Newcomer Socialization and Stress: Formal Peer Relationships as a Source of Support", Journal of Vocational Behavior, vol.54, p.453-470.

Aryee, S., Cheng, Y. W. and Chew, J. (1994), "An investigation of the predictors and outcomes of career commitment in three career stages", Journal of Vocational Behavior, vol.44, p.1-16.

Ballout, H. (2009), "Career commitment and career success: moderating role of self-efficacy", Career Development International, vol.14, p.655-670.

Baron, R.M., \& Kenny, D.A. (1986), "The moderator-mediator variable distinction in social psychological research: Conceptual, strategic, and statistical considerations", Journal of Personality and Social Psychology, vol. 51, p. 1173-1182.

Bas-Collins, A. (2007), ‘Human Resources: A Hidden Advantage?’ International Journal of Contemporary Hospitality Management, vol. 19, p.78-84.

Batt, R., Holman, D., and Holtgrewe, U. (2009), 'The GlobalizationBlau, J. G. (1985), "The measurement and prediction of career commitment", Journal of Occupational Psychology, vol.58, p.277-288.

Brislin, R. W. (1986), "The wording and translation of research instruments", Lohner, W. J. \& Berry, J.W. (Eds.). Field Methods in CrossCultural Research, 137-164. Beverly Hills: Sage.

Büssing, A. (1999), "Can control at work and social support moderate psychological consequences of job insecurity? Results from a quasiexperimental study in the steel industry", European Journal of Work and Organizational Psychology, vol.8, p.219-242.

Caesens, G., Marique, G., Hanin, D. \&Stinglhamber, F. (2015), “The relationship between perceived organizational support and proactive behaviour directed towards the organization", European Journal of Work and Organizational Psychology, DOI: $10.1080 / 1359432 \times .2015 .1092960$

Carson, K. D. \&Bedeian, A. G. (1994), "Career Commitment: Construction of a Measure and Examination of Its Psychometric Properties", Journal of Vocational Behavior, vol.44, p.237-262.

Chan, D. K. S. \& Cheng, Grand H. L. (2008), "Who suffers more from jobsecurity? A Meta-Analytic Review", Applied Psychology, vol. 57, p.272-303,

Chang, E. (1999), “Career commitment as a complex moderator of organizational commitment and turnover intention”, Human Relations, vol.52, p.1257-1278.

Colarelli, S.M., \& Bishop, R.C. (1990), "Career commitment: Functions, correlates and management", Group \& Organization Management, vol. 15, p.158-176.

Darden, W., Hampton, R., and Howell, R.D. (1989), "Career versus organizational commitment: Antecedents and consequences of retails salespeoples' commitment", Journal of Retailing, vol.65, p.63-77.

Dawson, M., Abbott, J. and Shoemaker S. (2011), "The Hospitality Culture Scale: A Measure Organizational Culture and Personal Attributes", International Journal of Hospitality Management,vol. 30, p.290-300.

De Cuyper, N. D., Mauno, S., Kinnunen, U., De Witte, H., Mäkikangas, A., \&Nätti, J. (2010), “Autonomy and workload in relation to temporary and permanent workers' job involvement: A test in Belgium and Finland”, Journal of Personnel Psychology, vol.9, p.40-49.

De Witte, H. (1999), "Job insecurity and psychological well-being: Review of the literature and exploration of some unresolved issues", European Journal of Work and Organizational Psychology, vol.8, p.155-177.

De Witte HH and Naswall K (2003), "Objective versus subjective job insecurity: Consequences of temporary work for job satisfaction and organizational commitment in four European countries", Economic and Industrial Democracy, vol. 24, p. $149-188$.

Eisenberger, R., Armeli, S., Rexwinkel, B., Lynch, P. D. and Rhoades, L. (2001), "Reciprocation of perceived organizational support", Journal of Applied Psychology, vol. 86, p.42-51.

Eisenberger, R., Fasolo, P. and Davis-La Mastro, V. (1990), "Perceived organizational support and employee diligence, commitment, and innovation", Journal of Applied Psychology, vol.75, p.51-59.

Erlinghagen, M. (2008), "Self-perceived job insecurity and social context: a multi-level analysis of 17 European countries", European Sociological Review, vol. 24, p.183-197. 
Ferrie J. E., Shipley, M. J., Marmot, M. G., Stansfeld, S. A., and Smith, G. D. (1998), "An uncertain future: The health effects of threats to employment security in white-collar men and women", American Journal of Public Health, vol. 88, p.1030-1036.

Ghiselli, R.F., La Lopa, J.M. and Bai, B., (2001), "Job satisfaction, life satisfaction, and turnover intent: among food-service managers", Cornell Hotel and Restaurant Administration Quarterly, vol.42, p.28-37.

Greenhalgh L. \& Rosenblatt, Z., (1984), “Job insecurity: Toward conceptual clarity”, Academy of Management Review, vol. 9, p. $438-448$.

Goulet, L R \& Singh, P. (2002), “Career commitment: A Reexamination and extension”, Journal of Vocational Behavior, vol.61, pp.73-91.

Hartley, L. J. A. (1998), Organizational Commitment and Job Insecurity in a Changing Public Service Organization, European Journal of Work and Organizational Psychology, vol.7, p.341-354.

Kusluvan S and Kusluvan Z (2000), "Perceptions and attitudes of undergraduate tourism students towards working in the tourism industry in Turkey", Tourism Management,vol.21 p.251-269.

Kidd, J. M., \&Smewing, C. (2001), "The role of supervisor in career and organizational commitment", European Journal of Work and Organizational Psychology, vol. 10, p.25-40.

Lam, T., Kowlon, H. H. and Zhang, H. Q. (2003), "Job satisfaction and organizational commitment in the Hong Kong fast food industry", International Journal of Contemporary of Hospitality Management, vol.15, p.214-220.

Lau, D. C. \&Liden, R.C. (2008), “Antecedents of coworker trust: Leaders' blessings”, Journal of Applied Psychology, vol 93, p.1130-1138.

Lent, R. W. \& Brown, S.D. (1996), "Social cognitive approach to career development: An overview", The Career Development Quarterly, vol.44, p.310-321.

Lin, C. P. \& Chen, M. F. (2004), “Career commitment as a moderator of the relationships among procedural justice, perceived organizational support, organizational commitment and turnover intentions", Asia Pacific Management Review, vol.9, p. 519-538

London, M. (1983), "Toward a theory of career motivation", Academy of Management Review, vol. 8, p. 620-630.

London, M. \& Noe, R. A. (1997), London's career motivation theory: An update on measurement and research, Journal of Career Assessment, vol.5, p.61-80.

Mathieu, J. E. \&Zajac, D. M. (1990), “A review and meta-analysis of the antecedents, correlates, and consequences of organizational commitment", Psychological Bulletin, vol 108, p. 171-194.

McAulay, B. J, Zeitz, G. \&Blau, G. (2006), "Testing a "Push-Pull" theory of work commitment among organizational professionals", The Social Science Journal, vol. 43, p.571-596.

Meyer, J. \& Allen, N. (1997), “Commitment in the workplace: Theory, research, and application”, Sage Publications.

Niu, H. J. (2010), "Investigating the effects of self-efficacy on foodservice industry employees' career commitment", International Journal of Hospitality Management, vol. 29, p. 743-750.

Otluoglu, Ç. K. O. (2012), "Protean and boundaryless career attitudes and organizational commitment: The effects of perceived supervisor support", Journal of Vocational Behavior, vol.80, p.638-646.

Otluoğlu, Ç. K. O. \&Ünsal A. B.S. (2015), "Perceived job insecurity, affective and normative commitment: The moderating effect of organizational career development opportunities"Psychology Human Resources Journal, vol.13, p.179-188.

Probst, T. M. (2003), "Development and validation of the job security index and the job security satisfaction scale: A classical test theory and IRT approach", Journal of Occupational and Organizational Psychology, vol.76, p. 451-467.

Podsakoff, P. M., MacKenzie, S. B., Lee, J. Y. and Podsakoff, N. P. (2003), “Common method biases in behavioral research: A critical review of the literature and recommended remedies", Journal of Applied Psychology, vol. 88, p.879-903.

Richardson, Scott (2009), "Undergraduates'perceptions of tourism and hospitaliyasa career choice", International Journal of Hospitality Management, vol.28, p.382-388.

Rousseau, K. R., Driver, M. J., Eneroth, K and Larsson, R. (1996), "Career pandemonium: realigning organizations and individuals", Academy of Management Executive,vol.10, p.

Sora, B., Caballer, A., Peiró, J. M., Silla, I., and Gracia, F. J. (2010), "Moderating influence of organizational justice on the relationship between job insecurity and its outcomes: A multilevel analysis", Economic and Industrial Democracy, vol. 31, p. 613-637.

Sverke, M. \&Hellgren, J. (2002), "The nature of job insecurity: Understanding employment uncertainty on the brink of a new millennium", Applied Psychology: An International Review, vol. 57, p. 23-42.

SVERKE, M. \& GoslingA, S. (2003), "THE CONSEQUENCES OF JOB INSECURITY FOR EMPLOYERS AND UNIONS: EXIT, VOICE AND LOYALTY", ECONOMIC AND INDUSTRIAL DEMOCRACY, VOL. 24, P. 241-270.

Tajfel, H., \& Turner, J. C. (1985), "The social identity theory of intergroup behavior", In S. Worchel, \& W. Austin (Eds.), Psychology of intergroup relations (2nd ed., pp. 7-24). Chicago: Nelson-Hall 
Tansky, J. W. \& Cohen, D. J. (2001), "The relationship between organizational support, employee development, and organizational commitment: An empirical study", Human Resource Development Quarterly, vol.12, p. 285-300.

Tharenou, P., Latimer, S. and Conroy, D. (1994), "How do you make it to the top? An examination of influences on women's and men's managerial advancement", Academy of Management Journal, vol.37, p.899-931.

Ugboro, I O \&Obeng, K. (2015), "The moderating effects of perceived threat to valued job features on career commitment among university professors", Australian Journal of Career Development, vol.24, p.39-52.

Vujicic, D., Jovicic, A., Lalic, D., Gagic, S. and Cvejanov, A. (2015), "The relation between job insecurity, job satisfaction and organizational commitment among employees in the tourism sector in Novi Sad", Economic and Industrial Democracy, vol.36, p.633-652.

Wallace, J. E. (1995), “Organizational and PROfESSiOnal commitment in PRofessional and nonprofessional ORganizations”, Administrative SCIENCE QUARTERLY. VOL.40, P. 228-255.

Whitener, E. M. (2001), “Do "high commitment" human resource practices affect employee commitment? A cross-level analysis using hierarchical linear modeling", Journal of Management, vol.27, p.515-536.

Zeytinoglu, I.U., Denton, M., Davies, S., Baumann, A., Blythe, J., and Boos, L. (2007), “Associations between work intensification, stress and job satisfaction: The case of nurses in Ontario", Relations Industrielles/Industrial Relations, vol.62, p.201-222.

Zeytinoglu I. U., Keser, A., Yılmaz, G., Inelmen, K., Ozsoy, A. and Uygur, D. (2012a)," Security in a Sea of Insecurity: Job Security and Intention to Stay among Service Sector Employees in Turkey", International Journal of Human Resource Management, vol.23, p.2809-2823. 